\title{
High Incidence of Lipid Deposition in the Liver of Rats Fed a Diet Supplemented with Branched-Chain Amino Acids under Vitamin $B_{6}$ Deficiency
}

\author{
Tae KAIMOTO $^{1}$, Mayumi SHIBUYA ${ }^{1}$, Kazutaka NishiKAWA ${ }^{2}$ and Hideo MAEDA ${ }^{2}$ \\ ${ }^{1}$ Department of Living Science, Shikoku University, Tokushima, Tokushima 779-1192, Japan \\ ${ }^{2}$ Faculty of Health and Living Sciences, Graduate School of Education, Naruto University of Education, \\ Naruto, Tokushima 772-8502, Japan \\ (Received September 3, 2012)
}

\begin{abstract}
Summary Male Wistar rats were fed four diets composed of purified 20\% vitamin-free casein diet with $(+)$ or without $(-)$ vitamin $\mathrm{B}_{6}(7.0 \mathrm{mg}$ of pyridoxine $\mathrm{HCl} / \mathrm{kg}$ of diet $)$ and with $(+)$ or without $(-)$ branched-chain amino acids (BCAAs) of valine, leucine, and isoleucine (4.75\%): $\mathrm{B}_{6}(+) \mathrm{BCAA}(-) ; \mathrm{B}_{6}(+) \mathrm{BCAA}(+) ; \mathrm{B}_{6}(-) \mathrm{BCAA}(-)$; and $\mathrm{B}_{6}(-) \mathrm{BCAA}(+)$ for $21 \mathrm{~d}$. Among rats fed the $\mathrm{B}_{6}(-) \mathrm{BCAA}(+)$ diet, about a half showed lipid deposition in the liver. On the other hand, serum triacylglycerol levels in the $\mathrm{B}_{6}(-) \mathrm{BCAA}(+)$ group tended to be decreased. Hepatic triacylglycerol and cholesterol levels tended to increase in the $\mathrm{B}_{6}(-)$ $\mathrm{BCAA}(+)$ group compared with the other three groups. Serum apolipoprotein B and apolipoprotein $\mathrm{E}$ (apo E) levels in the $\mathrm{B}_{6}(-) \mathrm{BCAA}(+)$ group were the lowest among the three groups. In contrast, hepatic apo $\mathrm{E}$ levels in the $\mathrm{B}_{6}(-) \mathrm{BCAA}(+)$ group were the highest among the three groups. High-performance liquid chromatography of pooled serum of rats with lipid deposits revealed that triacylglycerol and cholesterol levels in very low-density lipoprotein (VLDL) were decreased compared with other diet groups. These results strongly suggest that one of the mechanisms of lipid deposition in rats fed a $\mathrm{B}_{6}(-) \mathrm{BCAA}(+)$ diet is due to impaired secretion of VLDL.
\end{abstract}

Key Words vitamin $\mathrm{B}_{6}$ deficiency, branched-chain amino acid, lipid deposition, triacylglycerol, very low-density lipoprotein

Branched-chain amino acids (BCAAs) composed of valine, leucine, and isoleucine are essential amino acids and account for about $40 \%$ of dietary essential amino acids in body protein and about $15 \%$ of total amino acids in muscle proteins (1). BCAAs play a role in delayed onset of muscle soreness and fatigue, and suppression of fatigue in the central nervous system $(2,3)$. BCAAs have been also used for the prevention of hepatic encephalopathy in patients with liver cirrhosis $(4,5)$. Recently, sport enthusiasts have created an increased demand for dietary supplements with BCAAs and have increased their consumption of BCAAs-enriched soft drinks.

The first step in the catabolism of BCAAs involves branched-chain aminotransferase (BCAT; EC 2.6.1.42), a common enzyme. This enzyme requires vitamin $\mathrm{B}_{6}$, which functions as a cofactor in many enzyme reactions of amino acid metabolism $(6,7)$. However, little information is available on the relationship between supplementation with BCAAs and the recommended daily allowance of vitamin $\mathrm{B}_{6}$. In addition, it is known that a high-protein diet (e.g., 70\% casein diet) under vitamin $\mathrm{B}_{6}$ deficiency has a negative impact on several biochemical parameters and leads to fatty liver in rats $(8-10)$.

Our previous study showed that providing supple-

E-mail: tae-kaimoto@shikoku-u.ac.jp mented BCAAs under vitamin $\mathrm{B}_{6}$ deficiency and a 20\% casein diet caused an accumulation of triacylglycerol in the liver, and individual differences in biological responses were observed (11). It is possible that a disorder of amino acid metabolism in the presence of vitamin $\mathrm{B}_{6}$ deficiency might influence the assembly of lipids and apolipoproteins and/or the secretion of lipoproteins. Among the serum lipoproteins, very low-density lipoprotein (VLDL) is present during endogenous lipogenesis in the liver and its major apolipoproteins are apolipoprotein (apo) B, apo C, and apo E (12). It is interesting to compare serum apo B and apo E levels, and hepatic apoE levels to evaluate lipid deposition, because apo B and apo $\mathrm{E}$ are key determinants responsible for cellular recognition and internalization of chylomicron remnants, VLDL, and high-density lipoprotein (HDL) $(13,14)$.

In this study, we investigated the possible mechanism of lipid deposition in the liver of rats fed with the supplementation of BCAA under vitamin $\mathrm{B}_{6}$ deficiency and suggested the presence of impaired secretion of VLDL into the bloodstream from the liver.

\section{Materials and Methods}

Diets and animals. Four diets composed of purified $20 \%$ vitamin-free casein diet with $(+)$ or without $(-)$ vitamin $\mathrm{B}_{6}(7.0 \mathrm{mg}$ of pyridoxine $\mathrm{HCl} / \mathrm{kg}$ of diet) and with $(+)$ or without $(-)$ branched-chain amino acids 
Table 1. Composition of the experimental diets $(\mathrm{g} / \mathrm{kg})$.

\begin{tabular}{|c|c|c|c|c|}
\hline Ingredient & $\mathrm{B}_{6}(+) \mathrm{BCAA}(-)$ & $\mathrm{B}_{6}(+) \mathrm{BCAA}(+)$ & $\mathrm{B}_{6}(-) \mathrm{BCAA}(-)$ & $\mathrm{B}_{6}(-) \mathrm{BCAA}(+)$ \\
\hline$\alpha$-Cornstarch & 569.5 & 522 & 569.5 & 522 \\
\hline Casein & 200 & 200 & 200 & 200 \\
\hline Corn oil & 80 & 80 & 80 & 80 \\
\hline Sucrose & 100 & 100 & 100 & 100 \\
\hline Mineral mixture ${ }^{1}$ & 35 & 35 & 35 & 35 \\
\hline Vitamin mixture $^{1}$ & 10 & 10 & 0 & 0 \\
\hline $\begin{array}{l}\text { Vitamin mixture } \\
\qquad\left(\text { Vitamin } \mathrm{B}_{6} \text { free }\right)^{1}\end{array}$ & 0 & 0 & 10 & 10 \\
\hline DL-Methionine & 3 & 3 & 3 & 3 \\
\hline Choline bitartrate & 2.5 & 2.5 & 2.5 & 2.5 \\
\hline Leucine & 0 & 20 & 0 & 20 \\
\hline Valine & 0 & 15 & 0 & 15 \\
\hline Isoleucine & 0 & 12.5 & 0 & 12.5 \\
\hline
\end{tabular}

\footnotetext{
${ }^{1}$ Mineral (AIN-93G) and vitamin (AIN-93) mixes were obtained from Oriental Yeast Co., Ltd., Tokyo, Japan.
}

(BCAAs) of valine, leucine, and isoleucine $(4.75 \%)$ were used (15): $\mathrm{B}_{6}(+) \mathrm{BCAA}(-) ; \mathrm{B}_{6}(+) \mathrm{BCAA}(+) ; \mathrm{B}_{6}(-)$ $\mathrm{BCAA}(-)$; and $\mathrm{B}_{6}(-) \mathrm{BCAA}(+)$ for $21 \mathrm{~d}$ (Table 1). Male Wistar rats, 4 wk of age, weighing 75-80 g, were fed the $\mathrm{B}_{6}(+) \mathrm{BCAA}(-)$ diet ad libitum for $7 \mathrm{~d}$ as they adjusted to their new environment; they were then assigned to one of the four groups and given free access to diet for $21 \mathrm{~d}$. Each group used six rats except for the $\mathrm{B}_{6}(-) \mathrm{BCAA}(+)$ group, which used 12 rats. Animals were individually housed in a controlled room temperature $\left(24^{\circ} \mathrm{C} \pm 2\right)$ and light cycle (lighting 8:00 to 20:00). Rats were deprived of food for $4 \mathrm{~h}$ before sacrifice and were bled from the abdominal aorta under anesthesia by ethyl ether. Livers were immediately removed, frozen in dry ice, and stored at $-70^{\circ} \mathrm{C}$ pending analyses. This study was conducted in accordance with the guidelines established by the Japanese Society of Nutrition and Food Science, and the experimental protocol was approved by the Institutional Animal Care and Use Committee of Shikoku University.

Isolation of lipoproteins and purification of apo E. Isolation and purification of VLDL $(d<1.006 \mathrm{~g} / \mathrm{mL})$ using preparative ultracentrifugation from pooled serum of male Wistar rats and delipidation of VLDL were performed as described previously (16-18). Delipidated VLDL (40-45 mg) was solubilized in $6 \mathrm{M}$ guanidine $\mathrm{HCl}$ and $0.05 \mathrm{M}$ Tris- $\mathrm{HCl}\left(\mathrm{pH} 8.4\right.$ ) containing $0.1 \% \mathrm{NaN}_{3}$ and was applied on Sepharose CL-6B. Apo E fractions corresponding to a molecular weight of 34,000-36,000 were exhaustively dialyzed against distilled water, lyophilized, and used for calibration of apo E.

Enzyme-linked immunoassay (ELISA) of serum and hepatic apolipoproteins. Serum apo B levels were determined using an ELISA kit (Uscn, Life Science, Inc., Wuhan, China). Serum and hepatic apo E levels were determined as follows. Polyvinylchloride microtiter plates were coated with the diluted rat serum in carbonate buffer ( $\mathrm{pH}$ 9.6) containing $0.02 \% \mathrm{NaN}_{3}$ at $4^{\circ} \mathrm{C}$ overnight. For the preparation of liver samples, liver was homogenized with PBS buffer ( $\mathrm{pH} 7.4$ ) and an aliquot of solution was freeze-dried. Delipidation of freeze-dried liver was performed as described previously (18). Delipi- dated liver was solubilized with carbonate buffer $(\mathrm{pH}$ 9.6) containing $0.02 \% \mathrm{NaN}_{3}$, and the supernatant was used for coating plates. Apo E levels were measured by ELISA using two antibodies against goat anti-rat apo $\mathrm{E}$ as a first antibody (Santa Cruz Biotechnology, Inc., CA, USA) and horseradish peroxidase conjugated rabbit anti-goat IgG as a second antibody ( $\mathrm{R} \&$ G Systems, MN, USA). The procedure was previously described in detail

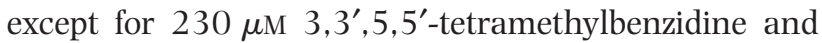
$0.02 \% \mathrm{H}_{2} \mathrm{O}_{2}$ in $200 \mathrm{~mm}$ citrate buffer ( $\mathrm{pH}$ 5.3) (19). The developed color was determined at $450 \mathrm{~nm}$ for apo B and apo E with a microplate reader (model 680, Bio-Rad Laboratories, Richmond, CA, USA).

Lipoprotein analysis. Serum lipoproteins were analyzed by an on-line dual detection high performance lipid chromatography (HPLC) system (Skylight Biotech, Inc., Akita, Japan) according to the procedure described by Usui et al. $(20,21)$.

Lipid analysis and other measurements. Hepatic lipids were extracted and purified according to the method of Folch et al. (22). Hepatic triacylglycerol, phospholipid, and cholesterol levels were determined colorimetrically as previously described (23). Serum triacylglycerol, phospholipids, and HDL cholesterol were determined using an enzymatic assay kit (Wako Pure Chemical Industries, Ltd., Osaka, Japan). Serum total cholesterol, albumin, and aspartate aminotransferase levels were determined by Fuji DRI-CHEM 3030 (Fuji Film Medical Co., Inc., Tokyo, Japan). Protein concentrations of the liver protein and purified apo E protein were determined using with bovine serum albumin as the standard (24).

Statistical analysis was performed using the TukeyKramer multiple range test. All statistical tests were done with SPSS 14.0J for Windows (SPSS Inc., IL, USA). A $p$ value $<0.05$ was considered statistically significant.

\section{Results and Discussion}

Growth parameters and tissue weight of rats fed different diets are shown in Table 2. After $21 \mathrm{~d}$, fat infiltration of the liver was observed via gross examination, liver weight per body weight, and hepatic triacylglycerol 
Table 2. Growth parameters and tissue weight of rats fed experimental diets.

\begin{tabular}{|c|c|c|c|c|}
\hline & $\mathrm{B}_{6}(+) \mathrm{BCAA}(-)$ & $\mathrm{B}_{6}(+) \mathrm{BCAA}(+)$ & $\mathrm{B}_{6}(-) \mathrm{BCAA}(-)$ & $\mathrm{B}_{6}(-) \mathrm{BCAA}(+)$ \\
\hline Final body weight (g) & $300 \pm 28^{a}$ & $294 \pm 13^{\mathrm{a}}$ & $239 \pm 10^{b}$ & $228 \pm 15^{b}$ \\
\hline Food intake $(\mathrm{g} / \mathrm{d})$ & $17.9 \pm 2.7^{\mathrm{a}}$ & $17.3 \pm 2.1^{\mathrm{a}}$ & $14.1 \pm 1.9^{\mathrm{b}}$ & $13.3 \pm 1.9^{\mathrm{b}}$ \\
\hline Liver weight (g) & $12.6 \pm 1.4$ & $12.2 \pm 0.3$ & $10.6 \pm 1.2$ & $11.6 \pm 1.6$ \\
\hline Liver (g/100 g BW) & $4.22 \pm 0.09^{b}$ & $4.15 \pm 0.17^{\mathrm{b}}$ & $4.44 \pm 0.37^{\mathrm{b}}$ & $5.08 \pm 0.58^{\mathrm{a}}$ \\
\hline Kidney (g/100 g BW) & $0.75 \pm 0.04^{\mathrm{b}}$ & $0.76 \pm 0.07^{b}$ & $0.97 \pm 0.05^{\mathrm{a}}$ & $0.97 \pm 0.07^{\mathrm{a}}$ \\
\hline $\begin{array}{l}\text { Epididymal adipose tissue } \\
(\mathrm{g} / 100 \mathrm{~g} \mathrm{BW})\end{array}$ & $1.51 \pm 0.40^{\mathrm{a}}$ & $1.33 \pm 0.12^{\mathrm{ab}}$ & $1.00 \pm 0.17^{b c}$ & $0.95 \pm 0.17^{\mathrm{c}}$ \\
\hline $\begin{array}{l}\text { Perirenal adipose tissue } \\
\quad(\mathrm{g} / 100 \mathrm{~g} \mathrm{BW})\end{array}$ & $0.41 \pm 0.12^{\mathrm{ab}}$ & $0.50 \pm 0.11^{\mathrm{a}}$ & $0.34 \pm 0.10^{b}$ & $0.29 \pm 0.06^{b}$ \\
\hline Thymus (g/100 g BW) & $0.26 \pm 0.03^{\mathrm{a}}$ & $0.32 \pm 0.04^{\mathrm{a}}$ & $0.14 \pm 0.01^{b}$ & $0.10 \pm 0.05^{b}$ \\
\hline
\end{tabular}

The preparation of experimental diets and its abbreviation are described in Table 1.

Values are means \pm SD of six rats except for 12 rats of the $\mathrm{B}_{6}(-) \mathrm{BCAA}(+)$ group. Different superscript letters indicate significant differences at $p<0.05$.

Table 3. Serum and hepatic lipid concentrations and growth indices of rats fed experimental diets.

\begin{tabular}{|c|c|c|c|c|}
\hline & $\mathrm{B}_{6}(+) \mathrm{BCAA}(-)$ & $\mathrm{B}_{6}(+) \mathrm{BCAA}(+)$ & $\mathrm{B}_{6}(-) \mathrm{BCAA}(-)$ & $\mathrm{B}_{6}(-) \mathrm{BCAA}(+)$ \\
\hline \multicolumn{5}{|l|}{ Serum } \\
\hline Triacylglycerol (mg/dL) & $236 \pm 71$ & $191 \pm 48$ & $160 \pm 80$ & $154 \pm 55$ \\
\hline Phospholipids (mg/dL) & $175 \pm 24$ & $166 \pm 22$ & $159 \pm 19$ & $143 \pm 26$ \\
\hline Total cholesterol (mg/dL) & $81.8 \pm 7.9$ & $80.8 \pm 11.5$ & $81.8 \pm 5.7$ & $81.8 \pm 14.6$ \\
\hline HDL-cholesterol (mg/dL) & $48.9 \pm 3.7$ & $47.7 \pm 6.8$ & $46.2 \pm 4.5$ & $46.2 \pm 5.8$ \\
\hline Aspartate aminotransferase (U/L) & $60.8 \pm 5.5^{\mathrm{b}}$ & $75.7 \pm 11.7^{\mathrm{a}}$ & $18.8 \pm 6.7^{\mathrm{c}}$ & $24.0 \pm 4.7^{\mathrm{c}}$ \\
\hline Albumin $(\mathrm{g} / \mathrm{dL})$ & $3.70 \pm 0.17^{\mathrm{ab}}$ & $3.58 \pm 0.17^{b}$ & $3.95 \pm 0.21^{\mathrm{a}}$ & $3.89 \pm 0.22^{\mathrm{a}}$ \\
\hline \multicolumn{5}{|l|}{ Hepatic lipids (mg/g liver) } \\
\hline Triacylglycerol & $16.9 \pm 6.1$ & $12.8 \pm 3.2$ & $20.5 \pm 3.3$ & $44.6 \pm 40.9$ \\
\hline Phospholipids & $27.8 \pm 2.1$ & $29.9 \pm 0.9$ & $28.0 \pm 2.2$ & $27.7 \pm 2.2$ \\
\hline Total cholesterol & $2.34 \pm 0.54^{\mathrm{ab}}$ & $2.03 \pm 0.18^{b}$ & $2.60 \pm 0.30^{\mathrm{ab}}$ & $3.61 \pm 1.54^{\mathrm{a}}$ \\
\hline
\end{tabular}

Values are means \pm SD of six rats except for 12 rats of the $\mathrm{B}_{6}(-) \mathrm{BCAA}(+)$ group. Different superscript letters indicate significant differences at $p<0.05$.

Table 4. Serum and hepatic apolipoprotein levels of rats fed experimental diets.

\begin{tabular}{lcccc}
\hline & $\mathrm{B}_{6}(+) \operatorname{BCAA}(-)$ & $\mathrm{B}_{6}(+) \operatorname{BCAA}(+)$ & $\mathrm{B}_{6}(-) \mathrm{BCAA}(-)$ & $\mathrm{B}_{6}(-) \mathrm{BCAA}(+)$ \\
\hline Serum & & & & \\
$\quad$ Apolipoprotein B (mg/dL) & $28.6 \pm 2.8^{\mathrm{ab}}$ & $24.0 \pm 6.7^{\mathrm{b}}$ & $33.7 \pm 4.4^{\mathrm{a}}$ & $16.9 \pm 5.0^{\mathrm{c}}$ \\
$\quad$ Apolipoprotein E (mg/dL) & $22.9 \pm 9.2^{\mathrm{a}}$ & $13.9 \pm 7.3^{\mathrm{ab}}$ & $10.6 \pm 5.4^{\mathrm{ab}}$ & $8.0 \pm 7.8^{\mathrm{b}}$ \\
$\quad$ Hepatic & $72.9 \pm 18.6$ & $57.4 \pm 23.7$ & $69.9 \pm 10.4$ & $128 \pm 101$ \\
$\quad$ Apolipoprotein E (ng/mg protein) & & & \\
\hline
\end{tabular}

Values are means \pm SD of six rats except for 12 rats of the $\mathrm{B}_{6}(-) \mathrm{BCAA}(+)$ group. Different superscript letters indicate significant differences at $p<0.05$.

levels in six of 12 rats fed the $\mathrm{B}_{6}(-) \mathrm{BCAA}(+)$ diet. Final body weight and food intake were significantly lower in the two $\mathrm{B}_{6}(-)$ groups compared with the two $\mathrm{B}_{6}(+)$ groups. The relative liver weight in the $\mathrm{B}_{6}(-) \mathrm{BCAA}(+)$ group was significantly increased compared with the other three groups. The relative kidney weight of the two $\mathrm{B}_{6}(-)$ groups was significantly increased compared with that of the two $\mathrm{B}_{6}(+)$ groups, and the relative epididymal adipose tissue weight of the $\mathrm{B}_{6}(-) \mathrm{BCAA}(+)$ group was significantly lower than that of the two $\mathrm{B}_{6}(+)$ groups. In addition, the relative thymus weight of the two $\mathrm{B}_{6}(-)$ groups was significantly decreased compared with that of the two $\mathrm{B}_{6}(+)$ groups.

Results in growth parameters and tissue weight in $\mathrm{B}_{6}$ deficiency were similar to a previous study (11).

Serum and hepatic lipids levels and growth indices are shown in Table 3. Aspartate aminotransferase activity of the two $\mathrm{B}_{6}(-)$ groups was significantly decreased to one third of the two $\mathrm{B}_{6}(+)$ groups. Serum triacylglycerol, phospholipids, cholesterol, and HDL-cholesterol levels were not remarkably different among the four groups. 


$$
\mathrm{B}_{6}(+) \mathrm{BCAA}(-)
$$

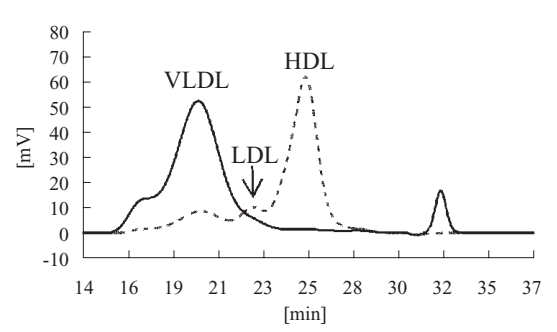

$\mathrm{B}_{6}(-) \mathrm{BCAA}(-)$

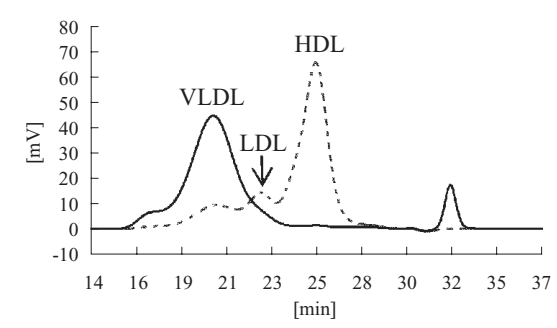

normal

$$
\mathrm{B}_{6}(-) \mathrm{BCAA}(+)
$$

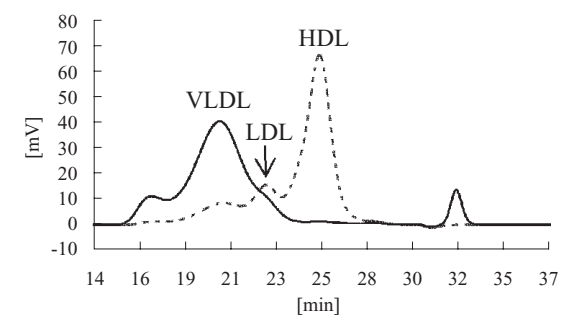

$\mathrm{B}_{6}(+) \mathrm{BCAA}(+)$

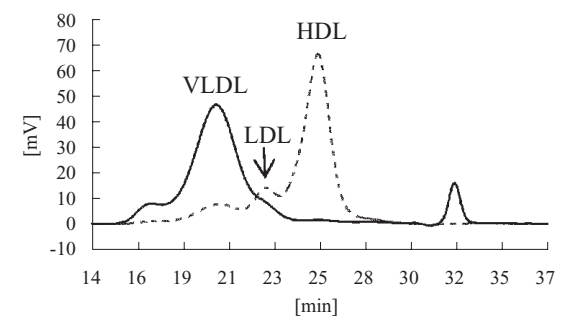

lipid-deposited $\mathrm{B}_{6}(-) \mathrm{BCAA}(+)$

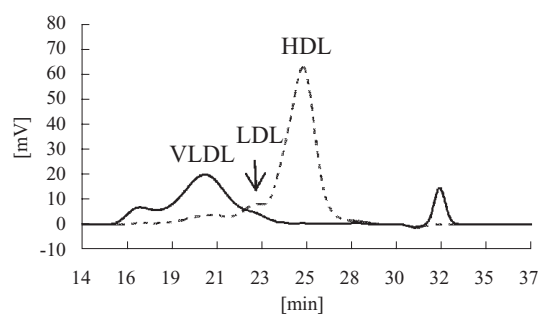

Fig. 1. HPLC profiles of serum lipid concentrations of lipoproteins of rats fed four different experimental diets. Pooled serum from each group was subjected to HPLC analysis, and triacylglycerol (solid lines) and cholesterol levels (dashed lines) in effluents were monitored. The retention times of very low-density lipoprotein, low-density lipoprotein, and highdensity lipoprotein were $20.5 \mathrm{~min}, 22.6 \mathrm{~min}$, and $25.5 \mathrm{~min}$, respectively. The composition of the experimental diets is described in Table 1 . The $\mathrm{B}_{6}(-) \mathrm{BCAA}(+)$ group was subdivided into two groups: normal liver or liver with lipid deposits, based on hepatic triacylglycerol levels.

Hepatic triacylglycerol and phospholipids levels were not significantly different among groups. However, hepatic triacylglycerol levels of the $\mathrm{B}_{6}(-) \mathrm{BCAA}(+)$ group were two to three-fold higher than those in the other three groups, although differences were not significant. The hepatic triacylglycerol levels of the 12 rats in the $\mathrm{B}_{6}(-) \mathrm{BCAA}(+)$ group ranged from 11.4 to $145 \mathrm{mg}$ per $\mathrm{g}$ liver, which may explain the differences compared with the other groups. Hepatic cholesterol levels in the $\mathrm{B}_{6}(-) \mathrm{BCAA}(+)$ group were significantly increased compared with the $\mathrm{B}_{6}(+) \mathrm{BCAA}(+)$ group.

These results that about half of the rats fed the $\mathrm{B}_{6}(-) \mathrm{BCAA}(+)$ diet showed lipid deposition in the liver were not experimental errors. Similar results were also observed in our previous report (11) and another three experimental results (unpublished data).

Serum and hepatic apolipoprotein levels determined by ELISA are shown in Table 4. Serum apo B and apo $\mathrm{E}$ levels in the $\mathrm{B}_{6}(-) \mathrm{BCAA}(+)$ group were the lowest among all groups, and apo $\mathrm{B}$ levels in the $\mathrm{B}_{6}(-)$ $\mathrm{BCAA}(+)$ group were significantly decreased compared with the other three groups. In addition, serum apo $\mathrm{E}$ levels in the $\mathrm{B}_{6}(-) \mathrm{BCAA}(+)$ group were also significantly decreased compared with that of the $\mathrm{B}_{6}(+)$ $\mathrm{BCAA}(-)$ group. On the other hand, hepatic apo E levels were not significantly different among the four groups, although apo E levels in the $\mathrm{B}_{6}(-) \mathrm{BCAA}(+)$ group were the highest among the groups. In this study, hepatic apo $B$ levels could not be determined because of insolubility of the characteristic of this apoprotein with the assay system (25). It is interesting to note that both hepatic triacylglycerol and apo E levels in the $\mathrm{B}_{6}(-) \mathrm{BCAA}(+)$ group tended to increase, but serum triacylglycerol, apo $\mathrm{B}$, and apo $\mathrm{E}$ levels tended to decrease. It is known that endogenously synthesized triacylglycerol in the liver is secreted as VLDL into the blood after being assembled with apolipoproteins such as apo B, apo C, and apo E as well as lipids (26). Therefore, it can be inferred from our data that the secretion of synthesized lipoproteins from the liver to the bloodstream might be impaired. As described in this study, hepatic triacylglycerol levels with the $\mathrm{B}_{6}(-) \mathrm{BCAA}(+)$ group of 12 rats ranged from 11.4 to $145 \mathrm{mg}$ per $\mathrm{g}$ liver. We then subdivided the $\mathrm{B}_{6}(-) \mathrm{BCAA}(+)$ group into two groups on the basis of hepatic triacylglycerol levels: 11.4 to $17.1 \mathrm{mg}$ per g liver was considered a normal liver, and 37.7 to $145 \mathrm{mg}$ per g liver was considered to represent lipid deposits. Then, the profile of serum lipoproteins was analyzed and compared among the three other groups and the two $\mathrm{B}_{6}(-)$ $\mathrm{BCAA}(+)$ subgroups.

HPLC analyses of serum lipoprotein profiles are shown in Fig. 1. The retention time of VLDL, LDL, and HDL were $20.5 \mathrm{~min}, 22.6 \mathrm{~min}$, and $25.5 \mathrm{~min}$, respectively. The pooled serum of lipid-deposited livers in the $\mathrm{B}_{6}(-)$ $\mathrm{BCAA}(+)$ group showed decreased triacylglycerol levels in VLDL compared with the $\mathrm{B}_{6}(-) \mathrm{BCAA}(+)$ group with no fatty liver deposits and with the other three groups. However, no differences in triacylglycerol or cholesterol levels of LDL or HDL were observed among these five groups. These lipoprotein profiles also support the mechanism by which the $\mathrm{B}_{6}(-) \mathrm{BCAA}(+)$ diet induced the lipid deposition in the liver due to the impaired secretion of VLDL from the liver into the bloodstream.

In this study, it is not clear why only half the rats fed 
the same diet developed lipids deposits in the liver and showed a divergent response under the same nutritional conditions. Further studies are underway to elucidate which factor(s) is more important in regulating hepatic triglycerol levels under BCAA supplementation and vita$\min \mathrm{B}_{6}$ deficiency.

\section{REFERENCES}

1) Ferrando AA, Williams BD, Stuart CA, Lane HW, Wolfe RR. 1995. Oral branched-chain amino acids decrease whole-body proteolysis. J Parenter Enteral Nutr 19: 47-54.

2) Shimomura Y, Yamamoto Y, Bajotto G, Sato J, Murakami T, Shimomura N, Kobayashi H, Mawatari K. 2006. Nutraceutical effects of branched-chain amino acids on skeletal muscle. J Nutr 136: 529S-532S.

3) Smriga M, Kameishi M, Torii K. 2006. Exercise-dependent preference for a mixture of branched-chain amino acids and homeostatic control of brain serotonin in exercising rats. J Nutr 136: 548S-552S.

4) Yoshida T, Muto Y, Moriwaki H, Yamato M. 1989. Effect of long-term oral supplementation with branched-chain amino acid granules on the prognosis of liver cirrhosis. Gastroenterol Jpn 24: 692-698.

5) Usui T, Moriwaki H, Hatakeyama H, Kasai T, Kato M, Seishima M, Okuno M, Ohnishi H, Yoshida T, Muto Y. 1996. Oral supplementation with branched-chain amino acids improves transthyretin turnover in rats with carbon tetrachloride-induced liver cirrhosis. J Nutr 126: 1412-1420.

6) Yennawar NH, Conway ME, Yennawar HP, Farber GK, Hutson SM. 2002. Crystal structures of human mitochondrial branched chain aminotransferase reaction intermediates: Ketimine and pyridoxamine phosphate forms. Biochemistry 41: 11592-11601.

7) Conway ME, Hutson SM. 2000. Mammalian branchedchain aminotransferases. Methods Enzymol 324: 355-365.

8) Okada M, Ochi A. 1971. The effect of dietary protein level on transaminase activities and fat deposition in vitamin $\mathrm{B}_{6}$-depleted rat liver. J Biochem 70: 581-585.

9) Okada M, Suzuki K. 1974. Amino acid metabolism in rats fed a high protein diet without pyridoxine. J Nutr 104: 287-293.

10) Suzuki K, Nakamura T, Fujita M, Iwami T, Abe M, Okada M. 1976. Factors affecting liver lipid content in pyridoxine-deficient rats. I. Dietary protein levels. J Nutr Sci Vitaminol 22: 291-298.

11) Kaimoto T, Kimura M, Hosokawa H, Shibuya M, Maeda H. 2012. Effects of branched-chain amino acid supplementation in rats fed a vitamin $\mathrm{B}_{6}$-deficient diet. Nippon Eiyo Shokuryo Gakkaishi (J Jpn Soc Nutr Food Sci) 65: 65-73.

12) Brown WV, Levy RI, Fredrickson DS. 1969. Studies of the proteins in human plasma very low density lipoproteins. J Biol Chem 244: 5687-5694.

13) Mahley RW, Innerarity TL. 1983. Lipoprotein receptors and cholesterol homeostasis. Biochim Biophys Acta 737:
197-222.

14) Mahley RW, Innerarity TL, Rall SC Jr, Weisgraber KH. 1984. Plasma lipoproteins: Apolipoprotein structure and function. J Lipid Res 25: 1277-1294.

15) Shimomura $Y$, Murakami $T$, Nakai N, Nagasaki M, Obayashi M, Li Z, Xu M, Sato Y, Kato T, Shimomura N, Fujitsuka N, Tanaka K, Sato M. 2000. Suppression of glycogen consumption during acute exercise by dietary branched-chain amino acids in rats. J Nutr Sci Vitaminol 46: $71-77$.

16) Maeda H, Hashimoto RK, Ogura T, Hiraga S, Uzawa H. 1987. Molecular cloning of a human apoC-III variant: Thr $74 \rightarrow$ Ala 74 mutation prevents O-glycosylation. J Lipid Res 28: 1405-1409.

17) Maeda $H$, Nakamura $H$, Kobori $S$, Okada M, Mori H, Niki H, Ogura T, Hiraga S. 1989. Identification of human apolipoprotein E variant gene: Apolipoprotein E7 (Glu244,245 $\rightarrow$ Lys244,245). J Biochem 105: 51-54.

18) Scanu AM, Edelstein C. 1971. Solubility in aqueous solutions of ethanol of the small molecular weight peptides of the serum very low density and high density lipoproteins: Relevance to the recovery problem during delipidation of serum lipoproteins. Anal Biochem 44: 576-588.

19) Maeda H, Miyamoto K, Sano T. 1997. Occurrence of dermatitis in rats fed a cholesterol diet containing field horsetail (Equisetum arvense L.). J Nutr Sci Vitaminol 43: 553-563.

20) Usui S, Hara Y, Hosaki S, Okazaki M. 2002. A new online dual enzymatic method for simultaneous quantification of cholesterol and triglycerides in lipoproteins by HPLC. J Lipid Res 43: 805-814.

21) Okazaki M, Usui S, Ishigami M, Sakai N, Nakamura T, Matsuzawa Y, Yamashita S. 2005. Identification of unique lipoprotein subclasses for visceral obesity by component analysis of cholesterol profile in high-performance liquid chromatography. Arterioscler Thromb Vasc Biol 25: 578-584.

22) Folch J, Lees M, Sloane-Stanley GH. 1957. A simple method for the isolation and purification of total lipids from animal tissues. J Biol Chem 226: 497-509.

23) Maeda H, Fujiwara M, Fujita K, Fukuda N. 1996. Hypertriglyceridemia and fatty liver of fasting rats after administration of emeriamine. J Nutr Sci Vitaminol 42: 111-120.

24) Smith PK, Krohn RI, Hermanson GT, Mallia AK, Gartner FH, Provenzano MD, Fujimoto EK, Goeke NM, Olson BJ, Klenk DC. 1985. Measurement of protein using bicinchoninic acid. Anal Biochem 150: 76-85.

25) Lee DM, Valente AJ, Kuo WH, Maeda H. 1981. Properties of apolipoprotein B in urea and in aqueous buffers: The use of glutathione and nitrogen in its solubilization. Biochem Biophys Acta 666: 133-146.

26) Gusarova V, Seo J, Sullivan ML, Watkins SC, Brodsky JL, Fisher EA. 2007. Golgi-associated maturation of very low density lipoproteins involves conformational changes in apolipoprotein B, but is not dependent on apolipoprotein E. J Biol Chem 282: 19453-19462. 